\title{
REGIONAL ECONOMIC GROWTH IN MEXICO: AN ANALYSIS OF TOTAL FACTOR PRODUCTIVITY
}

\author{
Noé Arón Fuentes* \\ Departamento de Estudios Económicos, El Colegio de la Frontera Norte \\ César M. Fuentes \\ Dirección Regional, El Colegio de la Frontera Norte, Cd. Juárez Chih.
}

(Received 12 july 2001, accepted 14 january 2002)

\begin{abstract}
This paper studies the character istics of recent regional changes in the Mexican manufacturing industry through an analysis of economic growth sources between 1975 and 1998 . On the hand side, the investigation is in response to the De León (1999) findings suggesting that there exists a negative productivity growth in the northern region. On the other hand, this investigation is motivated by the González-Aréchiga and Ramírez (1989) findings that suggest that productivity in the northern border region has increased as a consequence of the outward oriented policies, the free trade zone, and the assembly exports plants: Maquila. The obtained results indicate that the northern region showed positive gains in productivity and that the specific trade and development programs that were pursued by the Mexican government between 1975 and 1998 explain the changes in structure and productivity of the region.
\end{abstract}

\section{Resumen}

Este estudio examina las características de los recientes cambios regionales en la industria manufacturera mexicana a través de un análisis de las fuentes del crecimiento económico entre 1975-1998. Por un lado, esta investigación es una respuesta a los resultados obtenidos por De León (1999), los cuales muestran que existe un crecimiento negativo en la productividad de la región norte. Por otro lado, la investigáción es motivada por los resultados de GonzálezAréchiga y Ramírez (1989), „los cuales muestran que la productividad en la frontera norte ha aumentado como consecuencia de las políticas de apertura, la zona de libre comercio y las plantas ensambladoras exportadoras: Maquila. Los resultados obtenidos indican que la región norte del país presenta un incremento en la productividad y que los prográmas específicos de comercio y desarrollo que fueron instrumentados por el gobierno mexicano entre los años de 1975 y 1998 explican los cambios en la estructura y productividad de esta región.

JEL Clasification: 018, and 047.

Keywords: Regional Growth, Productivity Analysis.

* Departamento de Estudios Económicos, El Colegio de la Frontera Norte, Abelardo L. Rodríguez 2925, Zona del Río. 22320. Tijuana, B. C., Telephone: (52)664-6313535, E-mail: afuentes@colef.mx

The authors are very grateful to the anonymous referees for their comments. 


\section{Introduction}

It has been acknowledged that recent regional changes in Mexico since 1980 can be described as ones where economic activity has increased in the northern states and decreased in the largest cities. ${ }^{1}$ Many researchers have documented this trend that has become common knowledge among regional specialists in Mexico. $^{2}$ De León (1999), in an important contribution, describes the performance of manufacturing productivity from a regional perspective, based on an ad hoc regional classification, and on two productivity indicators: output by worker, and Total Factor Productivity $(T F P) .^{3}$

De León (1999) found that the largest cities maintained the highest level of productivity for the period 1975-1993. In contrast, the northern region showed a decrease in its productivity level for the same period compared to the national average. De León concludes that in the case of the northern region, its growth has been based on capital and employment growth rather than productivity. The author's results raise important reservations about the type of economic growth in the northern border region.

This study seeks first to identify the characteristics of recent regional changes in manufacturing through an analysis of economic growth sources between 1975-1998, and then to determine the causes of the changes that occurred. The first part of the investigation is in response to the De León (1999) findings that suggest that there exists a negative productivity growth in the northern region. The second part is motivated by the González-Aréchiga and Ramírez (1989) findings that suggest that productivity in the northern border region has increased as a consequence of the outward oriented policies, (Free Trade Zone) and industrial mix (assembly exports plants: Maquila). ${ }^{4}$

This study is similar to that of the De León's (1999) in two respects. Firstly, we use the same ad hoc regional classification to illustrate the dramatic changes in manufacturing output and employment growth among regions in the recent period. In particular, the regional classification presents, on the one hand, the participation of the three largest cities in the national output and employment and, on the other, the participation of the northern states. Second, we also provide a cross-sectional analysis of the sources of growth in Mexican manufacturing, comparing the variations in production inputs and $T F P$ among regions.

This study is different from that of the De León's (1999) in three aspects. First, this study estimates change in productivity in manufactures using the

\footnotetext{
1 For the regional classification see page 3 , in this text.

2 See Fuentes (1990), Polese and Pérez-Mota (1995), Gutiérrez(1994), De León(1999) and Calderón and Mendoza (2000).

3 Total Factor Productivity $(T F P$ ) is conventionally defines as the residual growth minus the increment in output. Thus, $T F P$ is identified as technological change.

4 Their model attemtps to account for variations in aggregate productivity resulting from regions differences in industrial mix and regional export oriented policies.
} 
transcendental logarithmic (Translog) production function, a methodology not yet applied to Mexico data (as far as we know). Second, TF P is estimated using a production function that includes intermediate inputs, rather than a valueadded function incorporating only labor and capital. Such approach discounts the assumption of separability between the prime factor inputs and material inputs, and recognizes that the inherent embodied technology in intermediate goods is a significant source of increased productivity (Gallop and Jorgenson, 1980). Finally, this study incorporates capital inputs based on actual values of capital stocks and costs, as reported in the industrial censuses of 1975, 1985, 1993 and 1998. Other attempts at measuring productivity in Mexican manufacturing have estimated capital inputs by projecting historical trends in capital formation and its contribution.

Our findings indicate, first, that manufacturing output grew in all regions, with the fastest growing rates for the northern, west-central, and central regions. The rest of the country grew modestly and the largest cities region kept pace with population growth. Second, TFP declined 0.1 percent during this period, indicating that production was slightly more efficient in 1975 than in 1998. The northern region showed positive gains in productivity while the central, west-central regions, and the largest cities declined in productivity during this period. Third, the changes in structure and productivity of the northern region are explained in the context of the specific trade and development programs that were pursued by the Mexican government between 1975 and 1998 . In other words, the industrial mix and export outward oriented policies had a positive effect on the northern border region productivity.

The structure of the paper is as follows. Section 2 presents the ad hoc regional classification adopted in this study. Section 3 describes the methodology employed in this study. Section 4 presents the data. Section 5 discusses the results obtained from the model. Finally, section 6 presents the conclusions.

\section{The ad-hoc Regionalization}

De León (1999) presents an ad hoc regional classification illustrating the dramatic changes in manufacturing output and labor growth among Mexican regions in the period $1975-1993$. Arccording to his opinion, this classification illustrates the recent regional changes in the Mexican manufacturing industry more clearly.

This regionalization presents, on the one hand, the participation of the three largest cities in the national output and employment and, on the other hand, the participation of the northern states. Both "regions" allow us to observe relevant location changes in economic activity, since they cover about 60 to 70 percent of total employment and about 80 to 90 percent of the output.

The rest of the states are classified as central, west-central, and rest of the country regions, according to industrialization and location patterns that present clear differences in economic performance. The regional classification refered to is presented in Map 1. 
Map 1. Mexican States Classification.

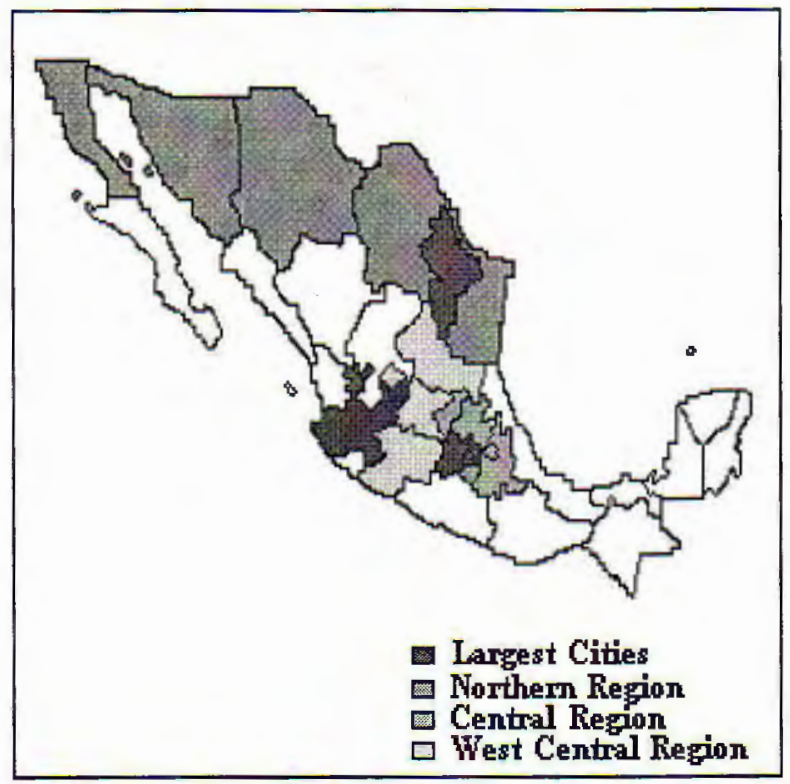

Specifically, Mexican states are classified as follow:

a) Distrito Federal, Jalisco, Estado de México, and Nuevo León are classified as the largest cities region. These states are characterized by manufacturing activities that were consolidated under the import substitution industrialization (ISI) and that feature the highest levels of output per worker in national manufacturing. ${ }^{5}$ They have also concentrated economic growth rates since 1950 and are the loci of the three largest industrialized cities in the country: Mexico City, Guadalajara and Monterrey.

b) The northern region includes the states of Baja California, Sonora, Coahuila, Chihuahua and Tamaulipas. Manufacturing in this region has been promoted by the Export Maquiladora Program since the 1960's and has been especially encouraged under the trade liberalization strategy. Tax subsidies, transportation cost advantages and agglomeration economies with the southern U.S. states are the strengths of the economic base for this region.

c) The central region includes the states of Hidalgo, Morelos, Puebla, Querétaro, y Tlaxcala. These states form a region of accelerated industrialization outside the largest cities and northern Regions.

d) The west-central region includes the states of Aguascalientes, Guanajuato, Michoacan, and San Luis Potosí. This region has steadily increased its participation in national manufacturing since the 1960's.

\footnotetext{
5 See De León (1999).
} 
e) The rest of the country region includes states as Baja Califormia Sur, Colima, Chiapas, Durango, Guerrero, Nayarit, Oaxaca, Quintana Roo, Sinaloa, Tabasco, Veracruz, Yucatán, and Zacatecas.

Using this ad hoc regional classification the author presents TF P estimates for the periods 1975-1985, 1985-1993, as well as for the 1975-1993. He followed the "conventional" methodology in growth accounting that allows us to identify productivity growth as a residual of output growth minus the weighted change in use of productive factors. In this way, TFP is identified as the change in output that cannot be attributed to change in use of productive factors, and that is defined more precisely as "doing more with less", the basic characteristic of economic growth.

Following this methodology, he assumes that manufacturing output (added value) in each state is a function of capital, labor and time, combined by means of a state production function. Then, the necessary conditions for the optimizing equilibrium of the state as a representative agent, and assuming constant returns to scale at the state level, imply that output elasticities in relation to capital and labor are equal to the participation of each productive factor in the total cost. Therefore, the share of capital and labor in relation to total cost is equal to one. In this way, the growth rate of output is expressed as the sum of the growth rates in the amount of capital and labor, each one weighted by their share in the total cost and total factor productivity.

De León's results show that during the period 1975-1998, regions that showed a positive rate of $T F P$ growth were the largest cities and the rest of the country region. The largest cities region is the only one that persistently showed a growth rate above the national average throughout the period. ${ }^{6}$ In contrast, the northern region showed a TFP growth rate that was persistently below the national average. The others regions showed mixed performances. For instance, the west-central region showed a negative $T F P$ growth rate before 1985 and an amazing positive $T F P$ growth rate after 1985 . The rest of the country region showed a different performance, that achieved a TFP growth rate above the national average before 1985, but one below the national average after 1985 . According to De León, all these changes in productivity performance confirm that productivity rates stagnate in the largest cities region, decreases in the northern region and has a positive performance in the rest of the country region, with a mixed performance in the west-central and central regions. These results allowed him to conclude that, in the case of the northern region, economic growth was based on capital and employment growth but not on changes in productivity.

\section{The Total Factor Productivity Measurement}

In this study, the model of production and technical change is based on the model introduced by Gallop and Jorgenson (1980) to study the United States

6 Although this is part of his conclusions, according to the data he presents, this statement is wrong. In fact, during the period 1970-1985, the northern states had a better performance than largest cities. 
productivity growth. Their model uses a Translog approximation to the production function and includes material inputs as a factor input along with labor and capital. A debate exists as to whether TFP should be measured using a value-added index or a production index, which includes intermediate inputs. Empirically, both procedures have been followed, depending on the availability of data, and the assumption of separability between labor and capital on one side and intermediate inputs on the other. Gallop and Jorgenson argue that intermediate inputs should be included in any estimate of TFP, because intermediate goods are substituted for capital and labor and contain embodied technology. In addition, the resultant gross production function (rather than the value added function) is the more widely accepted procedure in recent $T F P$ studies (Bonelli, 1992).

The initial assumption of the model used in this study, however, is that the true foreign currency indexes cannot be used in this instance, since they deal with discrete points in time rather than with instantaneous rates of change. In addition, reliable information on input prices was unavailable, so it becomes necessary to approximate the foreign currency index using other methods. This study applied the values of the inputs and outputs in each aggregate production function using the data provided in the census, rather than by estimating quantity indexes and multiplying them by price indexes obtained at the values. The final result is the same, except for the loss of flexibility in analyzing the changes in the price of individual inputs. ${ }^{7}$ In any event, the product of price and quantity indexes for intermediate inputs and outputs must equal the sum of the values, as presented in the industrial census. Therefore, this procedure ultimately provides the same measure of technical change from year $T-1$ to year $T$, as would one which incorporated additional price variables.

The process of measurement of the rate of change TFP is started by defining a production function which relates output to factor inputs and time. Here, the supposition is made that the net output of a production process depends on the quantities of factors of production that are employed: $Y=F(K, L, M, T)$, where $Y$ is output, $K$ is capital, $L$ is labor, $M$ are intermediate goods, and time $(T)$ is the term for technology (productivity) and is independent of the factors of production. Thus, the growth rate (denoted by $\wedge$ ) of output is the sum of the products of growth rates of each input and its respective share in total output value, plus the "unexplained residual", TFP, such that

$$
\hat{Y}=\alpha_{1} \hat{L}+\alpha_{2} \hat{K}+\alpha_{3} \hat{M}+\hat{T}
$$

written in logarithms for convenient statistical estimation, equation (1) becomes:

$$
\frac{\mathrm{d} \ln Y}{\mathrm{~d} t}=\sum_{i=1}^{3}\left(\frac{\partial \ln Y}{\partial \ln x_{i}}\right)\left(\frac{\partial \ln x_{i}}{\partial t}\right)+\frac{\partial \ln T}{\partial t}
$$

7 Having reliable data on price provides an alternative approach to measure $T F P$. The duality theory between prices and quantities states that the difference in changes in output and input values for given prices is equal to the difference between the input and output prices changes for given inputs and products. See, Elías (1992). 
where, $x_{i}$ is the set of inputs, $K, L$, and $M$, (i.e., $x_{1}=K, x_{2}=L$, and $\left.x_{3}=M\right)$. Notice also that

$$
\frac{\partial \ln Y}{\partial \ln x_{i}}=\alpha_{i}
$$

In order to calculate the weighted average of the growth rate of inputs (the middle term above), the elasticities of output as regards each of the inputs need to be determined. The assumption of producer equilibrium means that the elasticity of output as regards each of the inputs is equal to the respective share of that input in the value of total output. When individual prices for output and inputs are known, the value of inputs $\left(V_{i}\right)$ is expressed in the following equality by denoting the price of output by $P_{y}$ and the price of input by $P_{i}$ :

$$
V_{i}=\frac{P_{i} x_{i}}{P_{y} Y}=\frac{\partial \ln Y}{\partial \ln x_{i}}
$$

Substituting (3) in (2) yields

$$
\frac{\mathrm{d} \ln Y}{\mathrm{~d} t}=\sum_{i=1}^{3} V_{i} \frac{\partial \ln x_{i}}{\partial t}+V_{t}
$$

where

$$
V_{t}=\frac{\partial \ln T}{\partial t}
$$

The rate of technological change, or $T F P$, given as $V_{t}$ above is then calculated for each region, thus, providing a foreign currency quantity index for technological change. Quantity indexes for outputs and inputs, respectively, are similarly defined.

The indexes could be used to determine the rate of technical change at any point in time, but are not useful in this study because of the need to measure TFP between two points in time. According to Pinheiro (1989), the best procedure in this case is to approximate the foreign currency quantity indexes using Paasche approximation. This provides a measure of quantity change between two points in time, when both the total values and prices for each year are known. However, aš previously mentioned, reliable price indexes for each of the inputs were unavailable. Therefore, the alternative measure was to use the input and output values that are given in the industrial census, and to calculate technical change using Translog production function. In order to derive the rate of technical change between two points in time, $T$ and $T-1$, the average rate is expressed as the difference between successive logarithms of output and a weighted average of the differences between successive logarithms of inputs, with the weights given by average values shares. Again, the convention used by Gallop and Jorgensen (1980) is adopted:

$$
\ln Y(T)-\ln Y\left(T^{*}-1\right)=\sum_{i=1}^{3} V_{i}^{*}\left[\ln x_{i}(T)-\ln x_{i}(T-1)\right]+V_{t}^{*}
$$


where

$$
V_{i}^{*}=\frac{1}{2}\left[V_{i}(T)+V_{i}(T-1)\right]
$$

$Y(T)$ and $Y(T-1)=$ output at $T$ and $T-1$, respectively;

$V_{i}^{*}=$ average shares of each input in the total value of output; and

$V_{t}^{*}=$ average value of technical change.

The advantages of employing a Translog approximation to the production function, as opposed to the Cobb-Douglas $(C D)$, or Constant Elasticity of Substitution $(C E S)$ production functions are two-fold. First, the Translog function is quadratic in logarithms of the variables, which means it is more flexible in form, thereby reducing the threat of mis-measuring technical efficiency for industries whose production functions depart substantially from $C D$. In other words, the Translog function accommodates a wider range of input substitution possibilities than either the $C D$ or $C E S$ functions. Second, the more flexible form also gives the Translog function an advantage over the other two forms, when considering scale economies in some industries to be included in the estimations. Fortunately, their contribution to the total manufacturing output was less than 20 percent.

\section{Data Sources and Uses}

The data needed to estimate the parameter of the equation consists in output and inputs (labor, capital and raw materials) for the period 1975 through 1998 in constant Mexican pesos (converted to constant 1975 pesos) taken from the Industrial Census (1975, 1985, 1993 and 1998). Each of these variables are aggregated into five manufacturing regions to allow for comparisons of growth rates of outputs, inputs, and marginal productivities of each input and TFP.

The output values used in this analysis were taken directly from the industrial censuses of 1975, 1985, 1993 and 1998. All values are given in thousands of 1975 pesos, which meant that the 1985,1993 and 1998 values had to be deflated as they were stated in millions of current pesos. Due to inflation at that period of time, this deflator reflected an increase in prices of roughly 3100 percent. Data used to calculate the deflator were taken from Indicadores Económicos (Banco de México, 2000).

The labor input used in this model includes not only the wages actually paid during the year, but also social security and other payroll employer contributions. Thus, the total cost of labor for each of the years considered the average annual wage per employee times the average number of employees. ${ }^{8}$

The measurement of the stock of capital and/or its rate of growth is the most controversial aspect of TFP estimation. This is due to the fact that

8 The methodology in growth accounting suggests the use of worker-hour data, however, data are not available. Thus, we use a "proxy" variable: the number of workers. This assumes that all workers work tne same number of hours. 
differing views prevail as how to deal with the changing composition of capital, with separate attendant rates of return (or alternatively costs of capital), and with the problem of capital utilization.

Here, capital inputs were estimated based on actual values of capital and costs as reported in the Industrial Census. Interest of loans, rents paid for equipment and machinery, depreciation of capital assets, rents paid for buildings and land use were included in the estimate.

For the problem of capital utilization, the most used measure is to correlate use of capital with the utilization of electricity. As Kwon (1986) pointed out, to employ energy consumption in this way would amount to double counting as energy consumption is already considered in the material input in most cases. In addition, the lack of reliable data concerning electrical energy available to manufacturing prohibited the use of this measurement. Thus, a capacity utilization correction was not employed in this study.

The values of several types of material costs were incorporated into a single input value for each region. These categories included raw materials and intermediate products, electrical consumption, fuel and lubricants, water, outsource processing, and freight. The values as reported in the censuses include sales and value added taxes, when applicable, as the state owned enterprises were exempted for such payments. We use National Consumer Price Index from the Banco de México to convert expenditures on intermediate inputs into real terms.

\section{Results}

Growth in regional manufacturing output is presented in Table 1. The first and third column, labeled NDP-REG 1975 and NDP-REG 1998, indicate the total value of manufacturing production of each region in thousands of 1975 pesos. The last column shows the percentage change in the value of each region's output between 1975 and 1998. The largest cities, for example, increased its output from $1,644,275$ to $3,406,263$ thousands of pesos, or 107.16 percent from 1975 to 1998.

The second and fourth columns indicate the percentage of total manufacturing output that is attributed to each region each year. The Largest Cities, for example, reduced its participation to total output from 68.3 percent in 1975 to 46.7 percent in 1998. In contrast, the northern region increases its contribution to total output from 10.5 percent in 1975 to 16.7 percent in $1998 .^{9}$

As Table 1 shows, there was wide variation in regional growth. It ranged from 107.2 percent for the largest cities to a positive 804.2 percent for the

9 Output is reported for all manufacturing (NATIONAL) and for the five regions included in our empirical model. The growth of all manufacturing grew 203.04 percent, indicating that largest cities region is the only that increased its output at a slower rate than the NATIONAL (only by 107.14 percent). 
Table 1. Growth in Manufacturing Output for all Regions, 1975-1998.

\begin{tabular}{|c|c|c|c|c|c|}
\hline Region & NDP-REG & \% of NDP-Total & NDP-REG $^{1}$ & \% of NDP-Total & REG-Growth \% \\
\hline & 1975 & 1975 & 1998 & 1998 & $1975-1998$ \\
\hline Largest Cities & $1,644,275$ & 68.33 & $3,406,263$ & 46.71 & 107.16 \\
\hline Northern & 251,561 & 10.45 & $1,219,630$ & 16.73 & 384.82 \\
\hline Central & 215,546 & 8.96 & 930,269 & 12.76 & 331.59 \\
\hline West-Central & 91,023 & 3.78 & 823,025 & 11.29 & 804.19 \\
\hline Rest of Region & 236,835 & 9.84 & 912,787 & 12.52 & 285.41 \\
\hline National & $2,406,304$ & 100 & $7,291,974$ & 100 & 203.04 \\
\hline Northern $\mathrm{II}^{2}$ & 513,235 & 21.33 & $1,901,559$ & 26.08 & 270.5 \\
\hline
\end{tabular}

1 All output values in thousands of 1975 pesos.

2 Denotes the inclusion of Nuevo León as a part of the six northern states; $29.16 \%$ is the average growth of the northern states, $21.33 \%$ and $26.08 \%$ represent the northern states share of total output in 1975 and 1998 , respectively.

Source: Own calculations from Manufacturing Census 1975, and 1998. 
west-central region. Not surprisingly, largest cities and the northern region, which were the recipient of most of the government promotions and investment, accounted for the majority of the total output (the sum of their percentages was 63.44 percent of total in 1998). ${ }^{10}$

The Table 2 depict the changes in capital contribution and productivity that occurred between 1975 and 1998. The share of capital and the value of output by region results both from reallocation of capital resources and from change in the productivity of capital.

As the quantities in row $7\left(G M P_{K}\right)$ of Table 2 demonstrate, the marginal productivity of capital for all of manufacturing (NATIONAL) increased.30.9 percent during this period. The $M P_{K} 75$ was 1.39 percent. The $M P_{K} 98$ increase to 1.82 percent. Increasing capital productivity was not, however, a universal occurrence, as both the largest cities and central regions experienced drops in productivity (20.68 percent and 66.59 percent, respectively).

The rows in Panel A of Table 2 list the share of capital in the value of output for $1975\left(V_{K} 75\right)$ y $1998\left(V_{K} 98\right)$, the average between the years $V_{K} \mathrm{Avg}$, and the percentage growth in the capital input coefficient during the twenty three years period $\left(G V_{K}\right)$. Row 3, for example, shows that, on average, the share of capital in the value of national manufactured output was 0.4192 . The capital input in manufacturing increased 37.3 percent during the period, as evidenced in the first entry in row 4. ${ }^{11}$ However, the manufacturing in the northern region experienced a reduction in the share of capital, from 45.5 percent to 43.9 percent (column 3).

A decline in capital contribution can come from three sources: a reduction in the value of capital stock, or from a loss of return of capital, or both. The results for the northern region suggest that the decline in capital contribution can be attributed to the reduction in the return on capital assets (fixed) experienced during the period, rather than to investment in those assets. The data in Table 3 demonstrates this point. Column 1, denoted RFA-1975, shows the value of the return of fixed assets for each region in 1975. In the column 2, the rates of return on those fixed assets are listed. The next two columns show the same information for 1998, while the last column (\% in RFA) indicates the percentage change in the rate of return on fixed assets between 1975 and 1998 . For example, in the largest cities, the 25,116 thousands of pesos received as return on capital investment, in 1975 , a rate of 79.54 percent. Likewise, the

10 The west-central region spurred by the boom in economic activity during the maturity of ISI (1975-1980), and grew more than 800 percent but its impact was small in terms of total production: 11.29 percent in 1998. Also, central and rest of country regions experienced slow growth. They accounted for 12.76 percent and 12.52 percent of total production in 1998 , respectively.

11 This result supports Elías' (1992) finding that the contribution of capital to output growth increased even though the quality component (the financial rate of return to capital) actually declined. He found that the increase in investment was what boosted the overall capital input. Elías' study encompassed a 40 years period ending in 1985. 
Table 2. Capital Contribution to Growth in Manufacturing Regions, 1975-1998.

\begin{tabular}{|c|c|c|c|c|c|c|}
\hline \multicolumn{7}{|c|}{ Regions } \\
\hline & National & Largest Cities & Northern & Central & West-Central & Rest of Regions \\
\hline \multicolumn{7}{|c|}{ Panel A-Contribution of Capital } \\
\hline$V_{K} 75^{1}$ & 0.3532 & 0.3025 & 0.455 & 0.4177 & 0.4814 & 0.4974 \\
\hline$V_{K} 98$ & 0.4852 & 0.4265 & 0.4399 & 0.5603 & 0.4625 & 0.7086 \\
\hline$V_{K} \mathrm{Avg}$ & 0.4192 & 0.3645 & 0.44745 & 0.489 & 0.47195 & 0.603 \\
\hline$G V_{K}^{2}$ & 37.37 & 40.99 & -3.32 & 34.14 & -3.93 & 42.46 \\
\hline \multicolumn{7}{|c|}{ Panel B -Productivity of Capital } \\
\hline$M P_{K} 75^{3}$ & 1.39 & 2.32 & 1.92 & 4.97 & 2.91 & 0.38 \\
\hline$M P_{K} 98$ & 1.82 & 1.84 & 2.29 & 1.66 & 2.17 & 1.28 \\
\hline$G M P_{K}^{4}$ & 30.9 & -20.68 & 19.27 & -66.59 & -25.42 & 236.84 \\
\hline
\end{tabular}

1 Denotes share of capital in the value of output in 1975.

2 Denotes the change in the share of capital in the value of output between 1975 and 1998.

3 Denotes the marginal productivity of capital in 1975.

4 Denotes the percentage change in $M P_{K}$ between 1975 and 1998.

Source: Own calculations from Industrial Census, 1975 and 1998. 
Table 3. Growth in Return of Fixed Assets (RFA) in the Regions, 1975-1998.

\begin{tabular}{|c|c|c|c|c|c|}
\hline Regionn & RFA $^{1}-1975$ & Rate & RFA $^{1}-1998$ & Rate & $\%$ in Rates 1975-1998 \\
\hline Largest Cities & 25,116 & $79.54 \%$ & 27,199 & $41.63 \%$ & $-47.67 \%$ \\
\hline Northern & 8,732 & $55.65 \%$ & 7,907 & $29.43 \%$ & $-47.11 \%$ \\
\hline Central & 19,097 & $56.78 \%$ & 37,027 & $28.09 \%$ & $-50.52 \%$ \\
\hline West Central & 5,265 & $34.72 \%$ & 9,234 & $21.63 \%$ & $-37.72 \%$ \\
\hline Rest of Regions & 22,415 & $77.18 \%$ & 25,184 & $26.36 \%$ & $-65.84 \%$ \\
\hline National & 80,625 & $50.40 \%$ & 106.551 & $40.26 \%$ & $-20.83 \%$ \\
\hline
\end{tabular}

1 All in thousands of 1975 pesos.

Source: Own calculations from Manufacturing Census, 1975 and 1998. 
27,199 thousands pesos received in 1998 a 41.63 percent rate of return on the fixed assets accumulated in the same year. The drop in the rate of return from 79.54 percent in 1975 to 41.63 percent in 1998 was 47.67 percent, as indicated in the last column.

In real terms, the decline in capital return for all manufacturing was 20.83 percent, dropping from an average return in 1975 of 50.40 percent to 40.26 percent in 1998. Conversely, the value of fixed assets grew between 1975 and 1998. Table 4 shows the growth in the net value of fixed assets between 1975 and 1998 for each region. The first two columns contain the net value of fixed assets in 1975 and 1998 at thousands of 1975 pesos. Column three indicates how these values changed during the period. For example, for all manufacturing (national) fixed assets grew 309.94 percent (column three, last entry). Again, there was considerable variation in the growth in capital assets between the regions. As the data in column three indicate, the northern region almost multiply by five its capital stock with 368.80 percent increases.

By consolidating the results on marginal productivity and contribution of capital in the northern region, two conclusions can be made about the changes in capital accumulation, the productivity of the capital investment, and the use of capital in the production process. First, there is no apparent correlation between growth in net value of capital assets and productivity of capital. ${ }^{12}$ For example, note that the marginal productivity of capital $\left(G M P_{K}\right)$ increased 19 percent in the northern during this period, yet the elasticity ( $G V_{K}$ row 4, Table 2) actually declined 3.32 percent. This indicates that, in the northern region, firms proportionately used less capital in 1998 than in 1975, even though the productivity increased. Also, investment in fixed assets was higher than for all manufacturing average (368.80 percent against 309.94, Table 4). Second, a significant finding that emerged from the analysis of capital inputs was that capital in the northern region had become less important to the productive process. This was a direct result of the loss of capital return as the region experienced increases in investment.

Listed in Table 5 are the data concerning the changes in the productivity of labor and the contribution of labor to the growth in manufacturing by region between 1975 and 1998. The $M P_{L} 75, M P_{L} 98$ and the growth in labor productivity $\left(G M P_{L}\right)$ are listed in PANEL B. It is interesting to note that, unlike the productivity of capital, the overall productivity of labor increases 10.4 percent (first column). ${ }^{13}$ Also note that, in general, the greatest gains in labor productivity were in largest cities, central and rest of country regions (row 7). These results can be confronted with the data of the productivity of capital in the

12 This finding suggests that there were two kinds of capital investment taking place: 1)investment in capital that embodied technological progress (resulting in increased output over time from fewer inputs), and 2)investment in inefficient capital assets that served to expand capacity but not to increase productivity.

13 This result coincides with González-Aréchiga and Ramírez (1989), and González-Aréchiga and Ramírez (1989a) findings. They found that, in the northern region, there had been an increase in labor productivity without redistribution of income. 
- Table 4. Growth in Net Value of Fixed Assets by Region, 1975 - 1998.

\begin{tabular}{|c|c|c|c|}
\hline Region & Net Value & Net Value & Growth in Net value \\
\hline & of Fixed Assets 1975 & of Fixed Assets 1998 & of Fixed Assets \% 1975-1998 \\
\hline Largest Cities & 497,519 & $1,452,831$ & 192.01 \\
\hline Northern & 114,468 & 536,629 & 368.80 \\
\hline Central & 90,042 & 521,321 & 478.97 \\
\hline West Central & 43,283 & 380,667 & 779.48 \\
\hline Rest of Region & 117,819 & 646,885 & 449.04 \\
\hline National & 863,131 & $3,538,333$ & 309.94 \\
\hline
\end{tabular}

1 All values in thousands of 1975 pesos.

2 Only Manufacturing sector

Source: Own calculations from Manufacturing Census, 1975 and 1998. 
Table 5. Labor Contribution to the Growth in Manufacturing Regions, 1975-1998.

\begin{tabular}{|c|c|c|c|c|c|c|}
\hline \multicolumn{7}{|c|}{ Regions } \\
\hline & National & Largest Cities & Northern & Central & West-Central & Rest of Regions \\
\hline \multicolumn{7}{|c|}{ Panel A - Contribution of Labor } \\
\hline$V_{L} 75^{1}$ & 0.1659 & 0.1653 & 0.1652 & 0.1684 & 0.1581 & 0.1673 \\
\hline$V_{L} 98$ & 0.1088 & 0.1095 & 0.1691 & 0.0882 & 0.0763 & 0.0759 \\
\hline$V_{L} A v g$ & 0.1374 & 0.1374 & 0.1671 & 0.1282 & 0.1172 & 0.1216 \\
\hline$G V_{L}{ }^{2}$ & -34.42 & -33.76 & 2.3 & -47.74 & -51.74 & -54.63 \\
\hline \multicolumn{7}{|c|}{ Panel B - Productivity of Labor } \\
\hline$M P_{L} 75^{3}$ & 12.4 & 17.4 & 5.9 & 15.6 & 22.8 & 12.4 \\
\hline$M P_{L} 98$ & 13.69 & 40.72 & 6.98 & 21.63 & 21.68 & 23.80 \\
\hline$G M P_{L}{ }^{4}$ & 10.4 & 134.0 & 18.3 & 38.6 & -4.9 & 91.9 \\
\hline
\end{tabular}

1 Denotes share of labor in the value of output in 1975.

2 Denotes the change in the share of labor in the value of output between 1975 and 1998.

3 Denotes the marginal productivity of labor in 1975.

4 Denotes the percentage change in $M P_{L}$ between 1975 and 1998. Source: Own calculations from Industrial Census, 1975 and 1998. 
Table 2 (row 7 ). In the case of largest cities and central regions, the data show that, in these regions, the productivity of labor out-paced the productivity of capital.

The share of labor inputs $\left(V_{L} 75, V_{L} 98\right.$ and $V_{L} A v g$ ) and the changes in the value of these coefficients $\left(G V_{L}\right)$ are presented in PANEL A. Row 4 shows that the contribution of labor to the growth of manufacturing output $\left(G V_{L}\right)$ varied considerably among the regions, for example, for all manufacturing (national) it declined 34.42 percent. Although, for the northern region it increased 2.3 percent.

Considering the capital contribution to output growth, there are two possible causes for the increase in the share of labor input in the northern region. One is that the gross component of labor input, or number of employees, increased, thereby increasing the labor input. The other is that the quality component on real wage per employee was increased from earlier levels. It is not inconceivable that both could contribute to the increase in labor share output. The primary reason for the increase here, however, was that the big gains in employment during the twenty three year period were enough to overshadow the drop in real wages.

Table 6 demonstrates the regional variations in real wages per employee. The first two columns reveal the average wage per employee in thousands on 1975 pesos for each region. The last column indicates the percentage change in the value of real wages between 1975 and 1998. The northern region, for example, experienced the fourth lowest reduction in real wages per employee at 16.36 percent (row 2, column 3), down from 220 thousand pesos in 1975 to 184 thousand pesos in 1998 .

The data in Table 7 illustrate the changes that occurred in regional employment from 1975 to 1998 . Columns one and two show actual employment per region, while column three indicates the percentage change in employment from 1975 to 1998. Columns four and five indicate the share of each region in total employment for each year. For example, employment in the largest cities region increased only 61.2 percent bètween 1975 and 1998, and its share in total employment declined from 61.4 percent to 38.7 percent. Meanwhile, the northern region employment increased 494.3 percent between 1975 and 1998 , and its share in total employment increased from 11.4 percent to 26.5 percent. For all regions (national), employment grew 155.8 percent during the period. The data in Tables 5, 6 and 7 illustrate that the little increase in the labor contribution in the northern region between 1975 and 1998 was due to the modest reduction in real wages, but the impressive increase in the number of employees. 
Table 6. Growth in Real Wage per Enıployee by Region, 1975-1998.

\begin{tabular}{|c|c|c|c|}
\hline Region & \multicolumn{2}{|c|}{ Wage per employee } & Growth in wage per employee \\
\hline & 1975 & 1998 & $1975-1998$ \\
\hline Largest Cities & 268 & 228 & -14.92 \\
\hline Northern & 220 & 184 & -16.36 \\
\hline Central & 248 & 168 & -32.25 \\
\hline West-Central & 133 & 137 & 3.04 \\
\hline Rest of Region & 203 & 131 & -35.46 \\
\hline National & 241 & 187 & -22.40 \\
\hline
\end{tabular}

1 All wages are in thousands of 1975 pesos.

Source: Own calculations from Manufacturing Census, 1975 and 1998.

Table 7. Growth in Regional Employment, 1975-1998.

\begin{tabular}{|c|c|c|c|c|c|}
\hline Region & \multicolumn{2}{|c|}{ Employment } & Growth \% & \% of Total Enploynent \\
\hline & 1975 & 1998 & $1975-1998$ & 1975 & 1993 \\
\hline Largest Cities & $1,015,720$ & $1,636,979$ & 61.2 & 61.4 & 38.7 \\
\hline Northern & 188,629 & $1,121,064$ & 494.3 & 11.4 & 26.5 \\
\hline Central & 146,368 & 487,520 & 233.1 & 8.8 & 11.5 \\
\hline West-Central & 108,250 & 457,803 & 322.9 & 6.5 & 10.8 \\
\hline Rest of Region & 195,414 & 528,956 & 170.7 & 11.8 & 12.5 \\
\hline National & $1,654,381$ & $4,232,322$ & 155.8 & 100 & 100 \\
\hline
\end{tabular}

Source: Own calculations from Industrial Census, 1975 - 1998. 
The data in Table 8 demonstrate the contribution of intermediate inputs in the growth of regional output for 1975 and 1998. Included in PANEL A are the elasticities of output as regards intermediate inputs for each of the manufacturing sectors ( $V_{M} 75$ and $V_{M} 98$ ), as well as the percentage change in the values of the intermediate coefficients $\left(G V_{M}\right)$. In addition, the average value of material inputs $\left(V_{M} A v g\right.$ ) is given in row 3 .

The average share of materials in the value of output for all regions, for example, was 0.4635 , but it ranged from 0.447 in the northern region to 0.5003 in the west-central region. Overall, the contribution of materials to output increased its share by 6.85 percent $\left(G V_{M}\right.$, Column 1) from 1975 to 1998 . The northern region is the only one where intermediate inputs actually decreased its contribution in this period. ${ }^{14}$

PANEL B contains the coefficients of the marginal productivity of material inputs for each year ( $M P_{M} 75$ and $M P_{M}^{*} 98$ ) along with the percentage change in the productivity of materials between 1975 and 1998. In the northern region, the marginal productivity of materials ( $G M P_{M}$ ) declined by 31.43 percent.

As discussed by González-Aréchiga and Ramírez (1989), small use of national intermediate inputs is a characteristic of the industrialization process in the northern border's states. The authors contend that highly productive comntries use increasingly larger proportions of intermediate inputs in their production, and that these inputs contain increasing amounts of embodied technology. The authors found that material inputs decreased its share in output from 53.1 percent to 43.6 percent during the 1980 s in the northern region.

The results of the empirical measurement of TFP change by region are represented in Table 9. Contrary to the findings by De León (1999), that indicated a positive growth in productivity, this method indicates that $T F P$ in Mexico declines for all regions during the period between 1975 and $1998^{15}$ For all of manufacturing (TOTAL) the decline was 0.1 percent for the twentythree year period (Panel C, column "Total" and row five). This is significant because it indicates that TFP did not contribute positive to output growth. Most other studies have found a positive contribution of productivity to the growth process. ${ }^{16}$ A possible explanation for this is that the majority of studies have been conducted for shorter periods or during times of economic expansion and, unlike Mexico in the early $80^{\prime}$ s, did not include years where total output actually declined from previous years.

14 A reason could be the industrial mix. It is based on export assembly plants (mainly maquilas), where these plants import a great proportion of intermediate inputs.

15 De León (1999) used a valued added model in which to measure TFP from 1970 to 1993. He determined that TFP growth contributed 1.07 percent, capital 1.25 percent, to the growth of output. Average output growth was 3.63 percent. For a description of this model, refer to page 20 in Ph.D. dissertation.

16 See Elías (1992). 
Table 8. Intermediate Inputs Contribution to Growth by Regions, 1975-1998.

\begin{tabular}{|c|c|c|c|c|c|c|}
\hline \multicolumn{7}{|c|}{ Regions } \\
\hline & National & Largest Cities & Northern & Central & West-Central & Rest of Regions \\
\hline \multicolumn{7}{|c|}{ Panel A - Contribution of Intermediate Inputs } \\
\hline$V_{M} 75^{1}$ & 0.4481 & 0.4371 & 0.4837 & 0.4774 & 0.4764 & 0.4486 \\
\hline$V_{M} 98$ & 0.4788 & 0.4678 & 0.4102 & 0.5120 & 0.5243 & 0.5370 \\
\hline$V_{M} \mathrm{Avg}$. & 0.4635 & 0.4524 & 0.4470 & 0.4947 & 0.5003 & 0.4928 \\
\hline$G V_{M}{ }^{2}$ & 6.85 & 7.02 & -15.20 & 7.25 & 10.05 & 19.71 \\
\hline \multicolumn{7}{|c|}{ Panel B - Productivity of Intermediate Inputs } \\
\hline$M P_{M} 75^{3}$ & 3.44 & 2.52 & 3.34 & 2.40 & 1.98 & 8.40 \\
\hline$M P_{M} 98$ & 1.38 & 1.72 & 2.29 & 1.78 & 1.84 & 1.20 \\
\hline$G M P_{M}{ }^{4}$ & -59.88 & -31.74 & -31.43 & -25.83 & -7.07 & -85.71 \\
\hline
\end{tabular}

1 Denotes share of intermediate inputs in the value of output in 1975.

2 Denotes the change in the share of intermediate inputs in the value of output between 1975 and 1998.

3 Denotes the Marginal Productivity in intermediate inputs in 1975.

4 Denotes the change in $M P_{M}$ between 1975 and 1998.

Source: Own calculations from Industrial Census, 1975 and 1998. 
Table 9. Sources of Economic Growth in Mexico (in percent).

\begin{tabular}{|c|c|c|c|c|c|c|}
\hline \multicolumn{7}{|c|}{ Panel A - 1975-1985 } \\
\hline & Largest Cities & Northern & Central & West-Central & Rest of Regions & Total \\
\hline Output & 3.00 & 6.30 & 5.00 & 10.00 & 12.70 & 5.60 \\
\hline$M$ & 2.80 & 4.50 & 4.50 & 10.30 & 5.80 & 4.00 \\
\hline$K$ & 10.20 & 15.60 & 11.80 & 19.40 & 19.50 & 13.90 \\
\hline$L$ & 1.93 & 6.40 & 3.60 & 7.90 & 5.70 & 3.50 \\
\hline$T F P$ & -3.80 & -12.20 & -6.00 & -16.80 & -6.40 & -6.20 \\
\hline \multicolumn{7}{|c|}{ Panel B - $1975-1993$} \\
\hline & Largest Cities & Northern & Central & West-Central & Rest of Regions & Total \\
\hline Output & 4.00 & 3.60 & 8.57 & 13.48 & 9.30 & 6.44 \\
\hline$M$ & 3.66 & 3.69 & 9.31 & 14.39 & 10.52 & 6.71 \\
\hline$K$ & 5.68 & 4.28 & 9.80 & 16.64 & 11.30 & 8.74 \\
\hline$L$ & 2.83 & 4.81 & 5.67 & 11.07 & 4.13 & 4.81 \\
\hline$T F P$ & 0.06 & -0.87 & -1.36 & -5.37 & -2.81 & -0.97 \\
\hline \multicolumn{7}{|c|}{ Panel C - $1975-1998$} \\
\hline & Largest Cities & Northern & Central & West-Central & Rest of Regions & Total \\
\hline Output & 5.60 & 12.10 & 11.20 & 16.90 & 10.30 & 8.50 \\
\hline$M$ & 6.10 & 10.90 & 11.80 & 17.70 & 11.70 & 9.00 \\
\hline$K$ & 8.20 & 11.90 & 13.50 & 16.60 & 13.10 & 10.90 \\
\hline$L$ & 2.40 & 12.30 & 6.20 & 11.30 & 4.30 & 5.20 \\
\hline$T F P$ & -0.50 & 0.09 & -2.00 & -1.10 & -3.80 & -0.10 \\
\hline
\end{tabular}


Table 9. Sources of Economic Growth in Mexico (in percent). (continue)

\begin{tabular}{|c|c|c|c|c|c|c|}
\hline \multicolumn{7}{|c|}{ Panel D - 1985-1993 } \\
\hline & Largest Cities & Northerm & Central & West-Central & Rest of Regions & Total \\
\hline Output & 1.34 & 4.01 & 5.14 & 5.02 & -4.89 & 1.18 \\
\hline$M$ & 1.21 & 6.15 & 6.91 & 5.87 & 6.88 & 3.81 \\
\hline$K$ & -6.47 & -7.92 & -2.88 & -4.04 & -11.81 & -7.47 \\
\hline$L$ & 1.29 & 5.02 & 2.96 & 4.55 & -2.21 & 1.96 \\
\hline$T F P$ & 4.33 & 8.49 & 3.56 & 6.24 & 3.76 & 5.00 \\
\hline \multicolumn{7}{|c|}{ Panel E - $1985-1998$} \\
\hline & Largest Cities & Northern & Central & West-Central & Rest of Regions & Total \\
\hline Output & 2.50 & 5.80 & 6.20 & 6.90 & -2.30 & 2.90 \\
\hline$M$ & 3.30 & 6.40 & 7.20 & 7.30 & 6.00 & 4.90 \\
\hline$K$ & -1.90 & -3.80 & 1.70 & 2.80 & -6.40 & -2.90 \\
\hline$L$ & 0.50 & 5.90 & 2.60 & 3.40 & -1.40 & 1.80 \\
\hline$T F P$ & 2.10 & 6.00 & 1.10 & 5.80 & 1.70 & 2.83 \\
\hline
\end{tabular}

Source: Own calculations from Industrial Census, 1975 - 1998. 
Perhaps equally significant is the relatively small size of the TFP coefficients. Between 1975 and 1998 the change in $T F P$ ranges from a negative 3.80 percent in rest of country region to a positive 0.09 percent in northern region. Considered over a twenty-three years period, the annual variation is relatively insignificant. There are two explanations that account for this result. First, considering the performance of the national economy and all the negative influences that came to bear on some regions during this period, there actually was little productivity change. Second, the small changes in productivity resulted from improved measurement techniques over those employed in previous studies. These improved techniques, which include the translog production function, quantity and quality considerations in the values of labor and capital inputs, and the inclusion of intermediate inputs in the production process, have generally reduced the $T F P$ residual in most studies. Both explanations seem plausible, even though employing the improved methodology precludes direct comparison of our results with findings in other studies about Mexico.

Table 9 shows estimates of TFP by region for the 1975-1985, 1975-1993, 1975-1998, 1985-1993, and 1985-1998 periods. The findings lead to say that TFP contributed negatively to growth in output. As regards regional variations, PANEL C shows that in the period from 1975-1998 the only region that has shown a positive TFP is the northern region. Moreover, the northern region is the only one that persistently slıowed a $T F P$ above the national average throughout the period. In contrast, the largest cities showed $T F P$ that were persistently below the national average.

As discussed in the literature, the causes of $T P F$ change are the subject of much controversy. Most agree, however, that increasing productivity is reflected in higher returns to the primary factor inputs. Moreover, technological progress is the catalyst that promotes the gains in productivity. That is, not only do higher wages indicate increased skill levels, and higher capital returns from increased investment, and proper management of capital assets, but also there gains are made possible by the use of appropriate technology. The results determined here support this theory. The capital returns and real wages both declined dramatically during the period, indicating a drop in productivity.

\section{Conclusions}

This study sought to first measure the change in structure and productivity of manufacturing Mexican regions between 1975-1998, and then to determine the causes of the changes that occurred. The change in productivity was estimated using the translog production function, which is widely accepted as the best available methodology for this purpose. In addition, the research employed highly desagregated data concerning material and capital inputs, which have not been incorporated in previous studies of this type in Mexico. The results of the model of the sources of growth indicate the changes with respect to the structural make-up and productivity of manufacturing at a regional level during the period from 1975 to 1998 .

First, output for all manufacturing grew 203.04 percent, with the fastest growing regions being the west-central (804.19), northern (384.82), and central 
(331.59). The rest of country region grew only 285.41 percent, and the largest cities region kept pace with at 107.16 percent (see table 1).

Second, for the northern region the marginal productivity of capital increased 19.27 percent while the share of capital in the value of total output fell to 4.39 percent in 1998, indicating a 3.3 percent decline between 1975 to 1998 (table 2). The decline in capital contribution was the result of the loss in return on capital (table 3 ), as the value of fixed assets increase 368.80 percent (table 4).

Third, marginal productivity of labor increased 18.3 percent in the northern region, while the share of labor in the value of output increased 2.3 percent (table 5) as a result of a increase in employment (table 7). Overall real wage dropped 16.36 percent (table 6).

Fourth, TFP actually declined during the period, 1975-1988, 0.1 percent (table 9, panel C), indicating that production was more efficient in 1975 that in 1998. The northern region showed a modest gain in productivity, while largest cities declined in productivity 0.5 percent during the period. This indicates that productivity grew in some regions but overall it declined, contributing less to growth in 1998 than it did in 1975.

Five, the findings support those of González-A réchiga and Ramírez (1989a) suggesting that, in the case of the northern region, its growth has been based on capital and employment growth, but also in productivity.

Six, the findings confirm González-A réchiga and Ramírez hypothesis, that productivity in the northern border region has increased as a consequence of the outward oriented policies (free trade zone) and the industrial mix (assembly exports plants: Maquila).

\section{References}

Bonelli, T. C. (1992). A Note on Economic Growth and Productivity. Review of Economics and Statistics, 58(6), pp. 398-406.

Calderón C., and E. Mendoza (2000). Economías a Escala e Industria Maquiladora. Mimeo.

Carlino, G. A., and R. Voith (1992). Accounting for Differences in Aggregate State Productivity. Regional Science and Urban Economics, 22, pp. 597-617.

De León, A. (1995). Cambio Regional y Productividad en México. In Arroyo, J. and A. De León (Comp.). La Internacionalización de la Economía Jalisciense. Universidad de Guadalajara-UCLA, Guadalajara, México.

De León, A. (1995a). Liberalización Comercial y Desigualdad Regional: Exploración de la Evidencia e Implicaciones para México. In Arrollo J. and D. E. Lorey (Comp.). Ajustes y Desajustes Regionales. Universidad de Guadalajara-UCLA, Guadalajara, México.

De León, A. (1999). Endogenous Growth and Trade Liberalization: Explaining Differences in Urban Manufacturing Growth in Mexico. Ph.D. Thesis, Notre Dame.

Domínguez L., and F. Brown (1994). The Dynamics of Productivity Performance in Mexican Manufacturing (1984-1990). The Developing Economies, 31(3) pp. 279-298.

Elías, V. J. (1992). Sources of Growth: A Study of Seven Latin American Countries. Fundación Tucumán and The International Center for Economic Growth, ICS Press, San Fransisco. 
Fuentes, N. A. (1990). Estructura y Dinámica del Empleo a Nivel Regional. In GonzálezAréchiga, B. and J. C. Ramírez (Comp.). Subcontratacion y Empresas Transnacionales: Apertura y Restructuración en la Maquiladora. El Colegio de la Frontera Norte y Fundación Friedrich Ebert, Tijuana, B.C.

Gallop, N., and J. Jorgenson (1980). Production Function and Profit Function: The Measurement of Relative Economic Efficiency. Review of Economics and Statistics, 52.

González-Aréchiga, B., and J. C. Ramírez (1989). Productividad sin Distribución: Cambio Tecnológico en la Industria Maquiladora Mexicana (1980-1986). Frontera Norte, 1(1), pp. 97-124.

González-Aréchiga, B., and J. C. Ramírez (1989a). La Inversión Asiática en Baja California: Un Caso Diferente de Especialización. Trabajo Presentado en el Seminario: Reconversión Industrial, Inversiones Extranjeras y Territorios. Departamento de Teoría y Análisis de la Universidad Autónoma Metropolitana, Xochimilco, México, D.F.

Gutiérrez Vidal, M. (1994). Las Regiones de México ante el TLC, Comercio Exterior.

Hernández Laos, E. (1984). La Desigualdad Regional en México (1900-1980). In Cordera, R. and C. Tello (Eds.). La Desigualdad en México. Siglo XX.

Hernández Laos, E. (1997). Perspectivas del Desarrollo Regional en México Frente a la Globalización. Economía, Teoría y Práctica. Nueva Epoca, 7, pp. 79-106.

Krugman, P. (1991). Georgraphy and Trade. M.I.T. Press, Cambridge.

Krugman, P. (1993). Toward a Counter-Contrarevolution in Development Theory. Proceedings of the World Bank, Annual Conference on Development Economics.

Kwon, Y. (1986). TPF Growth in Manufacturing: Further Evidence from Corea. Journal of Regional Science, 3(33).

Livas E, R. and P. Krugman (1992). Trade Policy and Third World Metropolis. NBER, Working Paper No. 4238.

Moomaw, R. (1983). Spatial Productivity Variations in Manufacturing: A Critical Survey of Cross-Sectional Analysis. International Regional Science Review, 8, pp. 1-11.

Moomaw, R., and M. Williams (1991). Total Factor Productivity Growth in Manufacturing: Further evidence from the States. Journal of Regional Science, 1(31), pp. 17-34.

Pinheiro, R. (1989). The Source of TPF growth in Developing Countries. Economic Journal, 71.

Polese, M., and S. Pérez-Mota (1995). Integración Económica Norteamericana y Cambio Regional en México. Comercio Exterior, 45(2), pp. 132-138.

Reynolds, C., and F. J. Alejo (1987). Effects of Intersectorial Labor Shifts on Productivity Growth: Mexico's Experience and Implications for the United States. Indian Journal of Industrial Relations, 23(2), pp, 158-187.

Weiss, J. (1992). Trade Policy Reform and Performance in Manufacturing: Mexico (19751988). Journal of Development Studies, 29(1), pp. 1-23. 